\title{
近世における八溝山地附近の 紙問屋の立地について
}

野 村 勝 美

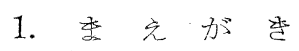

関東北部の分溝山地附诉（ここでいら八溝山地附近と以，問屋の分布と史料の収集の

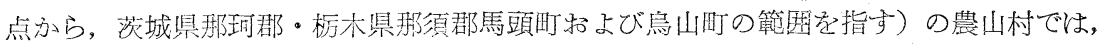
建保年間以来 700 年子の間，冬季農䦥副業として，絓方きが広く行われてきた。しかし 現在は盛んだつ它莦の面影は無く，少数の生産者が残存している汇過ざず，生産地も地 域的な収縮をみたのである。現在この地域行ける和絓生産は, 農䦥副業としてでは無 く，鳥山町（1954年の合併前の町域）の專業工場によつてその大部分がなされている。 この工場郡の形成は第二次大戦を契機とするるのであり，とれ以前は 1906 年創設の工 場ぶただ1つ存在したのみで，と礼とよるものを除いた和紙の生産はすべて農䦥期を利

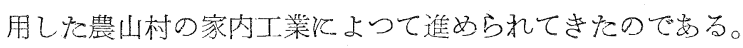

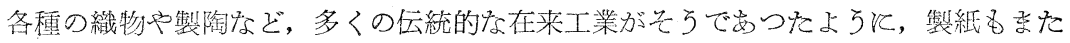
自給的家内手工業加発展して次第江商品化され, 経営形態の進化・生産額の增加・技 術の進歩なぞを伴って今日に至つている。八溝山地附近の製紙も近世後期には自給的生 産から商品的生産への著しい移行がるられた。近世の初め飞, 商品としての意味をあま り持たなかつた "紙”を, 後飞江戸表へ出荷するょう火なつたのは, 当地方農山村飞立 地した多くの紙問屋と江戸表の紙問屋によつて行われたのである。

さき飞，筆者は当地方の和紙生産の発展過程と現状についての概括的学考察を試及た が，本稿では前記のような專実基づいて，次のような観点から（特に，近世に和ける 紙閤屋の成立過程を中心沉）歴史地理的な教察を進めようとするものである。

(1) 近世の紙業地はでのようと分布していたか。

（2）近世の紙問屋は，産地とはどのような関係の位置に立地してか。

(3) 紙問屋々どのような過程で立地したふ。 
(4) 江戸との取引梳どのように行われたか。

な特，本稿は1955 年 11 月, 東京学芸大学地理学会例会汇祘いて発表したものに訂補を 加えたものである。

\section{2. 縒策地の分布}

古代・中世頃の製紙については，宝刍 5 年（774）の「正倉院文書」，延長 5 年 (927) の「延喜式」に下野国扔よび常陸国で紙を産したことが記録されているので，この頃ね は既に製紙が行われていたとる考克られるが，“国”という広い地域を指しているため，

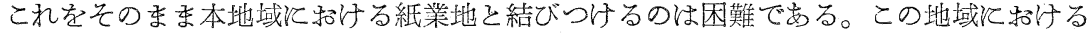
製紙の始采りは，口碑によると建保年間（1213-18）飞那須十郎なる者が励木県那須郡 烏山町大字向田に下，庄を開き，越前から漉立職を招いて那須奉書をすいたととである と伝えられている。(「鳥山町誌」による) とのように越前という先進地の技術の移入に よって紙すきが始まつたのであつたが，年そ共に生産地域の桩大・生産品種の增加をみ たものらしく，下野に括いては 16 世紀の末には大鷹紙（檀紙）・機留紙など数種の紙を 産出した。そして正保から正徳（1700年前後）に加けは，常陸の西野内・皮野沢・檜 沢・高部・大岩・小舟なごの諸村で，帳面紙・証畫用紙として賞用された“西ノ内紙”

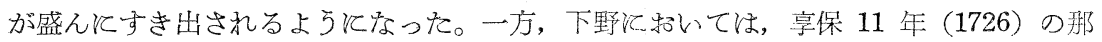
須郡酒主村諸色指出帳飞,

一, 諸職人員数之事 紙澽三人 金并町 勘右衛門 中町 宗左衛門 加ち町 喜左 街明

とありまた元㴚 15 年 (1702) の興野村の交畫には,

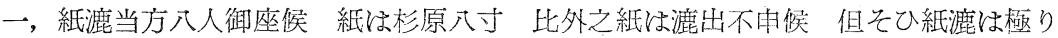
無御座候事

とあるととなどから，現在の烏山町の小字のいくつかで（酒主・興野も共鳥山町域内 である。)，それぞれ紙すきが行われていたことを知り得る。

これらの記録から，近世前世に括いても，この地域の和紙生産が相当盛えであつたこ とが知れるのであるが，まだ多分に自給的な傾向を持つ生産が行われていたと推測され るのである。

これに対して, 近世後期の紙業地ひ, 寛政 5 年(1793) の「諸国紙日記」（竹内源助の 書いた記録。以下「紙日記」と称する）路よび文政 9 年(1826）の「常陸紀行」（黒崎貞 
素) の記述から，その分布を知るととができる。「紙日記」には，当時の紙産地として 一檜沢・高部・大内・下小瀨・松之草・大䫅・鳥山・下堺・大沢・上堺・野上・向 田・刈立田・西之内一一空での諸村名が，紙名・枚数と共に記載されている。

杰炕，「常陸紀行」には次のようそ述べてある。

常陸国より紙を㶐すとと上古よりの事なり。今世紙の種類数多ありといれぞも，西野 内と称せるもの最も多し。久慈郡大沢・杤原を最上とす。夫よりして此藤・下小川・ 西金・相川の諸村は更なり。那珂郡鳥子・小田野・高部・上檜沢・下檜沢・氷野沢・上

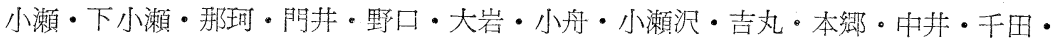
秋田・松野草・国長 - 野田・長倉・金井・大皇等，其他野州武茂郡大内 - 大那地 - 谷 川・多部・田谷, 又岡組・松野・富山等の諸村比屋皆紙を漉く事業とせり。常陸北部

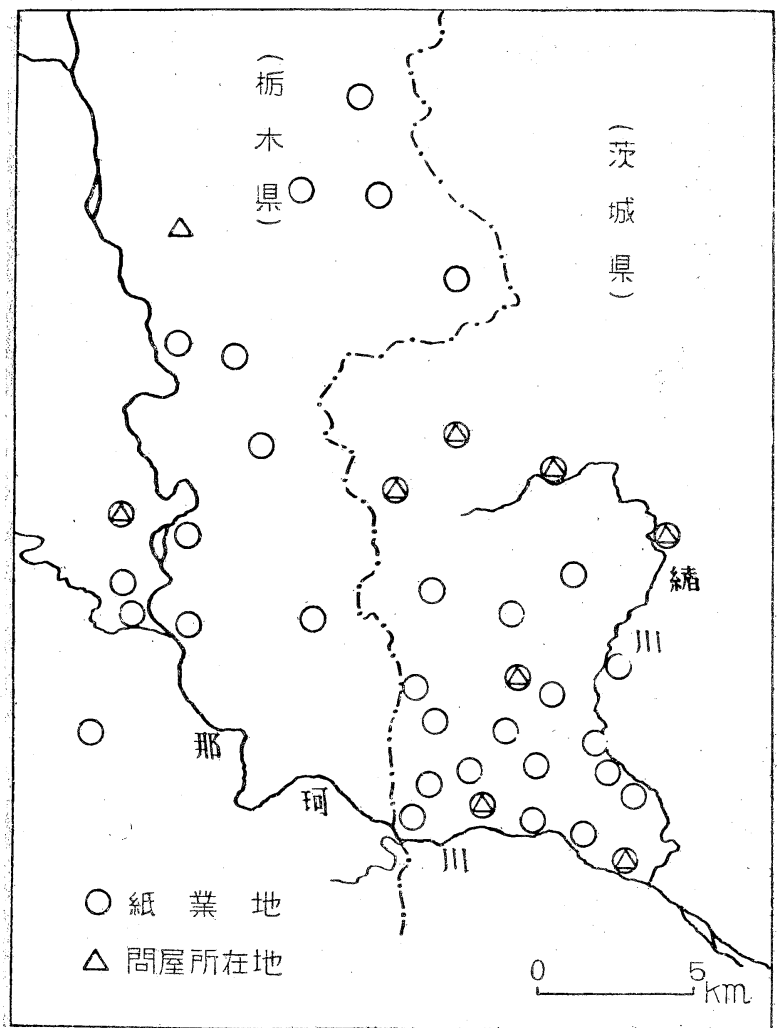

の産物第一とす。鳥子 村・薄井氏，富豪にし て紙をひさぐ事を業と し，郷中江名あり。其 他汇数ケ村中紙をひさ ぐ事を業とせるもの最 多し。(句読点・簕者) 以上の諸記録から作成 してのが第1図"近世末 （1800年頃）の紙産地・ 問屋の分布図”である。 分布の上では, 八溝山山 地南部の限られを地域に， 紙産地の集中しているの が特色である。当時の和 紙生産が，分布上江正ら れるような盛況を示す比 至った要因としては，分 溝山地隣接学る久慈川 沿岸地域が原料(コウゾ) 
の産地であつたこと，八溝山地に集中した産地が互に技術的に刺激し合つたり，あるい

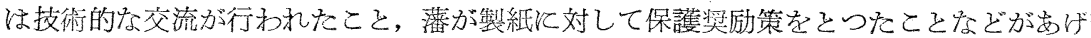

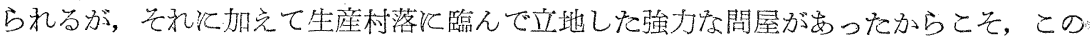
地域の和紙生産が近世としては比較的整った形態のもとで，盛んな発展をとげたと考え るととができるのである。

\section{3. 紙問屋の分布}

研究対象地域のう方，常陸（那珂地方と称する）に招ける近世後期の紙問屋分布は， 「紙日記」(1793)，筧政7年（1795）「紙売買掟書」などで明らかである。第 1 図には 「紙売買掟書」による 1795 年の紙間屋分布を村単位に示したが，間屋数は年代・文書 那珂埃方の紙間屋

\begin{tabular}{|c|c|c|c|c|c|}
\hline 村 名 & 名 & $\begin{array}{c}1973 \text { 年 } \\
\text { (紨日 記) }\end{array}$ & {$\left[\begin{array}{l}\text { 1795年 (紙 } \\
\text { 売置掟書) }\end{array}\right]$} & $\begin{array}{l}1822 \text { 年 } \\
\text { (小室交書) }\end{array}$ & $\begin{array}{l}\text { 年代不詳 } \\
\text { (大森交畫) }\end{array}$ \\
\hline \multirow{2}{*}{ 小田野 } & 川和 庄三鄎 & ○本問屋 布袋譵 & ○問 屋 & 川勾 任三郎 & 0 \\
\hline & 薄贲新助 & 新問屋 大福講 & - & - & 薄茾 新介 \\
\hline \multirow{2}{*}{ 鳥ノ子 } & 川积小右衛門 & ○本問屋 布袋講 & ○問 屋 & - & 川和善趡門 \\
\hline & 薄斗友右衛門 & ○新問屋 雑 ソ & ○間 屋 & 0 & 0 \\
\hline 上檜沢 & 長阔 三郎次 & ○問屋兹 大福講 & - & - & - \\
\hline \multirow{3}{*}{ 下檜沢 } & 小室藤次衛門 & ○問屋並 布袋講 & ○間 屋 & 0 & 0 \\
\hline & 平㴚次郎兵衛 & ○新問屋 布柋請 & ○問 屋 & - & - \\
\hline & 小室 弐郎太 & - & - & 小室 喜市䬦 & 0 \\
\hline \multirow{2}{*}{ 大 碞 } & 竹内 忠三䬦 & ○本問屋 布袋棓 & - & 竹内源助 & 竹内 源㬍 \\
\hline & 佐藤善次右門 & ○新問屋 大福講 & 二 & - & 0 \\
\hline \multirow{3}{*}{ 高 部 } & 墀江半重 & ○新問屋 大福講 & - & - & - \\
\hline & (国松)権兵衛 & - & ○問 屋 & 0 & 国松権兵衛 \\
\hline & 大森 又衛門 & - & - & 0 & 0 \\
\hline 松之草 & (会沢) 金兵衛 & - & ○仮問屋 & - & 会沢金兵衛 \\
\hline 野 口 & 関沢源治衛門 & $\mid O$ (小堌云人) & ○問 屋 & 0 & 0 \\
\hline \multirow{4}{*}{ 長 倉 } & 西田市郎衛門 & ○新問屋 住吉講 & ○問 屋 & 0 & ○ \\
\hline & (泉) 伊兵衛 & - & ○仮問屋 & 0 & 泉 伊兵衛 \\
\hline & か子要彦十郎 & $O$ (小 普 云 人) & $\begin{array}{c}\text { O仮問屋 } \\
\text { 彦 重 }\end{array}$ & 大森 彦重 & 大森 彦十 \\
\hline & (大森)产三郎 & - & 仮問屋 & - & 大森彦三䬦 \\
\hline 馬 頭 & 飯澱善左衛門 & - & ○問 屋 & - & 飯场 善衛閏 \\
\hline
\end{tabular}

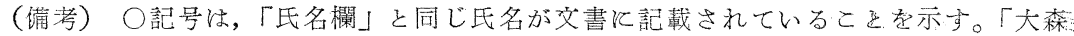
交書」は1830４0のものと思われる。 
そより異なつていて一定していない。それを整理すると前ぺ、ジ表のと新りである。

この表から, 那珂地方には多くの問屋が存在し, 内容も複雑であったととが了解でき るが，烏山を中心とする下野側はこれと異なつた状態がみられる。前述したようと烏山 （酒主村・興野村）は紙の生産地でもあったが，城下は生産よりも职引の盛えな土地で

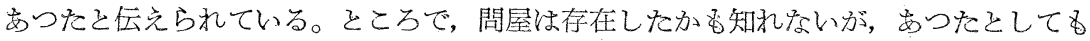
規模も小さいものだつたらしく，その状態を明らか沉し得る記録を欠いている。（町絵 図や 1834 年「下野鳥山領騒動記」などには "紙屋”という屋号が散兌されるが，それ が紙の売買を行った家を指しているとは断定できない。)

そして「紙日記」そよれば，城下では江戸の紙問屋が滞在して直接買入れ㐫たり， 城下近村で産する"大高”"十文字”などの糊入紙恬もちろんのとと，水戸領内で生産さ

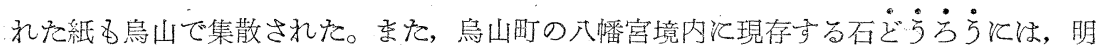

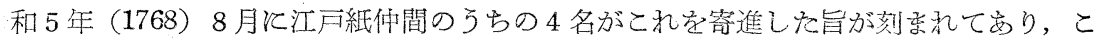
れからも江戸問屋の城下滯在が肯定でさる。前記した那珂地方の紬問屋と鳥山城下の江 戸問屋の関係については, 後に述べることにする。

\section{4. 紙問屋の成立過程}

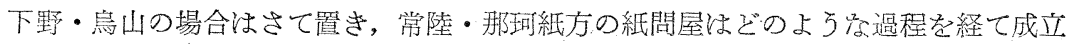
したのであるうか。これてついて述べるのが，本節の目的である。

わが国の近世封茟社会は農民社会を基礎として成立していだると，各地である程度

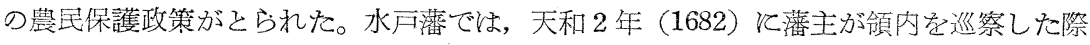
に，農村の困窮しているようすをみて，翌年から紙舟役などを免除することになつた。 かふる方策は，自給自足の経済組織を推持しょうとする藩にとつては，当を得た措置と いうべきであつた。しかし，その頃になると，江戸の紙間屋は次第に水戸領にも進出し， 生産者に前金を渡すととによつて，自己の勢力下に生産者老彷属させる傾问が生じてき た。これて対して灌では, 領内の自給自足の経済体制を推持し, 紆ずき(農村) を保護

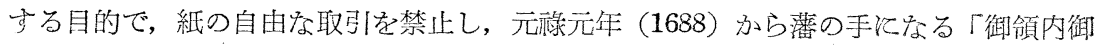
買絓」が始められたのである。このような経過は，次の記録によつて明らかである。

……西野氏筆記に，元䇐元年辰年より御領内御買紙始る。是は武茂保内筋紙嚰共へ

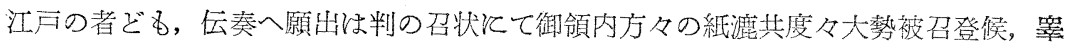
竞御国の者共幡者の様に相聞候付とかく御領内帒漉共江戸商人共より前金かり党候故 
每度眯り合出来候, 御手前買汇被遊候得ば江户商人との䀣合無之百姓子難儀不仕候々 御了簡任て江戸商人方上り前金かり候分莫大の金高不残御指替紙㭽共勝手取直次第運 々と御取立被遊候積り也云々，その頃よりも荷口銭を納められしが，筧文二年壬寅元 月二十五日命ありて是を許さる, 紙船役は元来出し来りしを天和二年義公御在国中铺 巡村季し委し，民の困第を御苦学化被為思召翌年六月二十三日命じて目前の有来諸役 の内七ケ条免除し給 5 内紙舟役も見へたり, 其後宝永の比上りか紙舟役出す様にな りそると云，迺其職の人に問ふべし，(日本農民史料聚粋）

御買紙の開始は, 常陸の紙を再び“萡”という領国単位の経済機構中々引き戻すかの ようと灭られたが，実際は藩自身がこれとは全く反対の方策をとつたのである。すなお

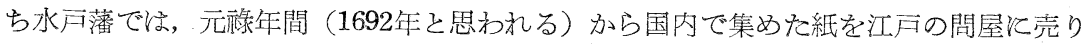
さばいたのでめつた。つ京り，藩自身が全国的な経済組織沫加わつたのであつた。この 紙御蔵は 20 数年の間続いたが，正德年間（1711-15）から休となつてしまつた。との 間の事情は判然としないが，紙御蔵の時に蔵役などを勤めた者が江戸問屋からの依賴な ぞもめり, やがて国元で問屋を始めたのである。乙か乙実際は, 紙御蔵の時代にも御蔵 紙の売払いなどは商人に委託して行つていたのであつたから,一御蔵の休業後にふ水らに 問屋営業を許したころで，さしたる支障は無く，かえつて冥加金などを受けることがで きて好都合で离つた。以下ね「紙日記」の一部であるが，紙問屋の設立過程が知礼ると 思うので，参考玉で記述する。

御領内紙問屋之次第

$\begin{array}{ll}\text { 小田野村 } & \text { 川和庄三郎 } \\ \text { 䧼子村 } & \text { 川和小右衛門 } \\ \text { 大岩村 } & \text { 竹内忠三郎 }\end{array}$

右三人之者共布袋講定宿本組第一番兌問屋也 其次第は元祿年中より正德年中迄甘 壱子年之間御国紙御蔵使来る 右三人其節右三人之者共先祖紙御蔵役勤め申候 夫 故江第一番之問屋株飞㴰成今以其之通御座候 則其之意味左之通御座候

一 御城米 五拾俵 小田野村 川和层兵衛 苗字带刀御免

一 右同断䉆 子 村川和善右衛門 右同断

右雨人御藏策江戸小梅御鋪江御蔵相立本町伝馬町御会所有 御郡御手代石川伊口衛

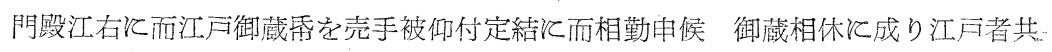
より相賴付付定宿に罷成申候（中略） 
一 御城米 二拾俵 大岩村 竹内惣左衛門 苗字帶刀御免

右之者義者元䇐年中御在々村に御蔵相立候節御蔵元改役に被仰付通り相勤由候故に 粐二拾俵被下候 江戸定宿者五十俵御座候

右以上三人本問屋古来株壱番組申候

こうして最初に問屋を初めた者を布袋講・古来株本問屋とし, 後にこれに加わつた本 問屋並の 8 の 2 軒, さらに 1780 年から問屋の届出のあつた新問屋 6 軒, 以上合計 11 軒 が「紙日記」に畫かれた問屋としてまげられるが，その外に「紙日記」には，

一、御国茋 小増云人と云へ．

一、当時 野口村 関沢源治衛門

一、同長倉村 加淽や彦十郎

右之類は江戸本問屋共江虫を買圆候賴候而売江戸者は都而口銭払利を見候を小せり 已云者申也

とあり，この 2 軒は（1795年には問屋・仮問屋になつを）問屋に準ずるものと考えられ る。

那珂地方に約する紙問屋は，以上のよ5ないきさつで成立したが，次にその立地に検 討を加えることにする。第2図は問屋の立地年代別の分布を示したるのである。布袋講 本問屋 3 軒は，八溝山地の内部に最も早く(正徳一敦保) 立地したが, 奏際は紙御蔵 （藩専売）の時から紙の移出・販壳に関係したことになる。問屋の集荷範团は記録上で は判然としないが，その分布からみて，互に重複するとと無しに周囲の村に及んでいた と推測される。その後にできた問屋並 2 軒は, いずれも本問屋の外側部に, 問屋の空白 地を満たず形で立地した。かような問屋の立地に伴い, その周辺での生産量も增加した ことであろう。ところが新問屋の立地（1780）は，本問屋・問晊並の既に存在した所に 割り込む形で行われた。つまり問屋相互の勢力疄の重複があつたと考克られる。それに もかかわらず, 多くの問屋が並存できたのは, 生産量の増大という裹付けがあったから である。

かくて安永末から寛政 6 年頃（1780-1794）にかけては，本問屋（3）・問屋並（2） ・新問屋（6）が集まつて株仲間を構成したが，その頃"小増”そいわれた問屋（野口 ・長倉各 1軒）は，それに入つていなかつた。かれらは江戸問屋の依賴で紙を調達した ので，実質的には他の問屋と全く同じであつた。野口の関沢家 1780 年の文書には，同 家が当時，紙商売渡世を行つたと記録されているので，新問屋よりも古くから紙商いを 
していたものと考光られる。

先にも少し触れてように，生産力の增大したととが，多くの問屋を好立可能としたと 考光るものであるが，各

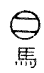

頭

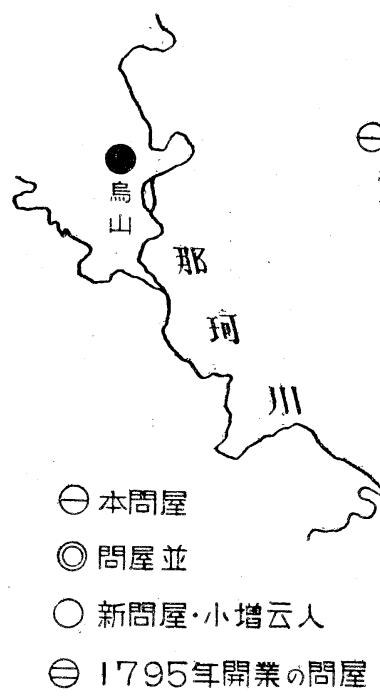

問屋は生産量の增加と自 己の报う製品を確保する こそに努力した。特に， 問屋仲間に入礼ずといた 関沢・大森 (加満や) の 両家注，他の問屋と競争 的な立場岕つたので, これ机力を入れた。各 問屋は製品を全部自己の もとと納入するのを条件 飞, 生産者汇原料を渡し, 必要に応じて金を前貸し し, 紙すき期の終了後に 貸借を清算する方法をと つた。本地域和いては, か上ろな問屋を䑶とい い，生産者（↔き子）を 舟前と称した。”舟前”を行つた問屋は，いずれる江戸の紙問屋から舴前を行うための 金を借りていた。このようなととが行われた結果，「紙日記」飞

一、右十一軒の内休口四て丸潰しも江戸商人共より大金借用有之候し不勘定致し候 故商人共手なり致し自然そ取行休飞申候 又紙漉よりもかり有之候 前後に敵を 請候処他江而取上兼候者共笑止千万之事共也 とあるようと, 先とあげた問屋のうち2 軒が休業, 8軒が「丸潰し」「半潰し」となっ てしまつた。それ対して野口・長倉の「小增云人」は，「中及本問屋位の有様」とい われたよう盛えであつた。

1795年になつて問屋仲間の再組織が行われ，那珂地方の紙問屋はすべて株仲間飞編入 されたのである。紙問屋は全文 18 简条から成る「紙売買掟書」を作成し，行司を置い 
て舟前を含を互の競争を避けて利益の存続をはかつたのである。しかし, 舟前はとの後 も根強く行われ，末た関沢家の「杂倠事控」によると問屋株仲間も崩壊のきざしがみられ そ。すなわち, 黑船来航後領内紙問屋と江戸との取引が不円滑となつたのと対して, 野州の烏山・茂木へは活潑飞荷が動くようそなり，江戸問屋もとれそ加わつている。こ のままでは「御国産第一の品衰微の基」そなるから，領内に 2 䈏所（長倉・小舟）の市 場会場をつくつてほしいというのである。

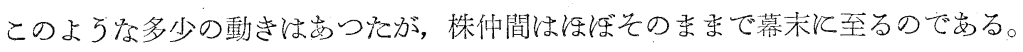

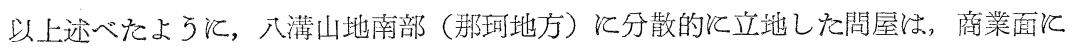
路いては本地域の製品を他地域飞移出し, 生産面では原料の支給・道具の貸付などを伴 つた問屋制家内工業を発達させた。しかる問屋と生産者の関係は，ただ単資本主えす き子とととどまらず，苗字带刀を許された名主・組頭ととのるととあつた一般村民とい う上下の関係をあわ持つていたのである。このよう問屋と生産者とが幾重にる堅く 結ばれていたために，各問屋を中心にした生産体制が確立されたのでるる。

\section{5. 製品の移出地域々取引方法}

本地域で生産された紙は，乙の地域に立地した多くの問屋てよつて他の地域へ移出さ れたが，大部分は江戸向けられ，それ以外の地送られた記録は見られない。那坷地 方に捻いては, その地の問屋が江戸の紙問屋と密接なつながりを持つて製品の移出にあ

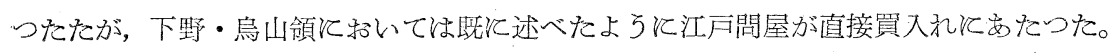
「紙日記」とは, 本地域と取引関係のあつた江戸紙問屋として, 布袋講 2 軒, 住吉講 1 軒，大福講 4 軒，計 7 軒の氏名を以下のようにあげてある。

江戸紙問屋本組壱番組

一、本石町四丁目

本家勢州大賀 大和屋三郎右衛門

一、大伝馬町壱町目

本家勢州松坂 小津清三衛門

右雨人布袋組他間之申候

一、本石町四丁目 村田彦左衛門 右一人 ムシ (住吉講) 組仲間と申候

一、本四町目 本家勢州 西村喜三郎 
一、本四丁目 同森治郎兵衛

村田七右衛門

一、大伝馬町三丁目

本店勢州まつ坂 小津次郎左衛門

右四人大福講と申候以上

七人是を本紙店本問屋と申候

紙問屋本組壱番組は，はじめは9軒であつたが寛政期には，そのうらの 2 軒が休業し， 7 軒となりていた。かれらは布袋講・住吉講・大福講の 3 組とわかれていて，それぞれ 異なつた取引方法があった。「紙日記」には，以下のように書かれている。（休業になつ た2軒とついての記述は省略する。)

布袋講住吉講大福講之次第左之通

……右江戸本組岳問屋九人之内式軒は潰し候 当時七人者繁昌也 布袋講と申者御 国江入込定宿に馬加り致し候 紙相調申候 大福講者御国江入込事表向绀不出来候 故に烏山城下に四人定宿を賴（常）時も罷有候 尤御国に而は内及紙相調（置）候 紙問屋有之候 然る所本荷造り致し印を打附候事罷成不申菰怆致し草荷と名付鳥山 定宿へ引取鳥山に而荷造江戸（江送）申 住吉講と申は御国江 も烏山江も下り不申 し（而）江戸並御国並汇諸国より紙持来之商人を江戸引請相払候を株任侯 則村 田彦左衛門当地壱人也 双布袋講大福講住吉講中不残同様汇参会致し然る所御国江

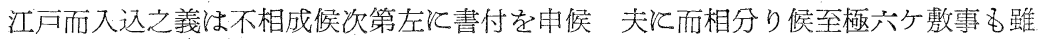
有之略之也口伝㐫り但乙御国江入込候義罷成不申候事有奈辺口伝

すなわち，江戸問屋の 5 ち布垡講飞属した問屋（大和屋三郎右衛門・小津清三衛門） は，常陸領内へ出向いて，在国の布袋講問屋を通じて紙を買入れた。

大福講（西村喜三郎・小森治郎兵衛・村田七右衛門・小津次郎左衛門）の者は，那珂 地方へ行つて取引をすることができないととになつていたので，との講の者 4 人は鳥山 そ滯在していた。そして常陸領内には，かような江戸間屋のために内々紙を調達する問 屋 (大福講) があつた。しふしその際に，紙を本荷造りして規定ど招りの印を押すとと はできなかつたので, しも包にし"草荷”と称して烏山の江戸問屋定宿へ送り, そこで 荷造をな招し、那須紙”として江戸へ出したのであつた。この事実は，鳥山㓮の八幡宮 境内にある石亡゙う்・によつて裏づけられる。それ刻季れた文字から, 明和 5 年 (17 68）に江戸紙仰間の西村権七・小森平兵衛・村田儀兵衛・小津伊兵衛ら 4 名（江戸問屋 


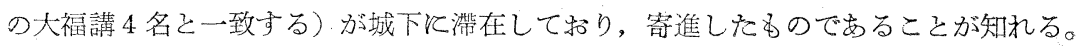
さて，住吉講（村田彦左衛鹏）は前の 2 者とは異なり，江戸ほいて諸国の紙商人が持 参する紙学買入れる方法をとつた。常陸紆間屋で住吉講を名乗つたのは1軒であつたが, 初め株仲間にはいつていなかつた関沢家なども，住吉講の村田彦左衛門と取引していた。

以上のことから，江戸問屋の 3 講と同様飞本地域の問屋もまた 3 組にわかれていたこ そが明らふである。ところが，1795年（株仲間の再組織）以後の諸記録には"諈"とい。 う交字は見られない。また「紙売買掟」・その他の文書などから，各問屋の 1795 年以 降の取引が判然とした講別の取引形態がみられず，鳥山の間屋を経るか，木たは江戸表 の問屋へ直接に紙を送つたことが了解できる。

八溝山地附近で生産された紲は，こうして江戸表へ送られた。このことは，近蚻後期

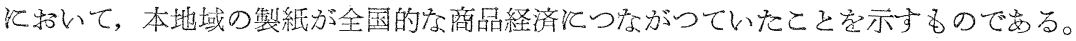

幕末至り, 社会の不安と動摇は，本地域で后天狗党と書生の争となつて表面化した。 この争乱は本地域の紙問屋にも及び，天狗に属した問屋の多くは書生の襲らところとな り，明治年間の問屋分布が烏山町に集中する要团の1つとなつた。

\section{6. むم す び}

以上を要約して結語とする。

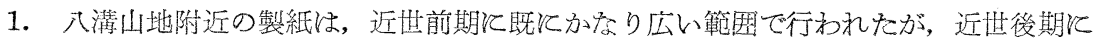
なると常陸・下野再国にわたつた広い地域で盛んに行われるようになつた。

2。近世後期の紙業地分布に伴い，紙問屋もやはり広い範田に分散的に分布していた。 そして製品は，江户へ移出された。

3. 常陸側には紙問屋が存在し，株仲間を構成していたのに対し，下野・烏山には江戸 紙間屋が湩在し，直接買入に岁たつた。

4. 1795年をでは, 那珂地方の間屋は江戸問屋と同様な 3 講を組織し、それぞれ異なつ た方法で取弱它行った。

5.1795年飞常陸紙問屋仲間の再組織が行われ, 間屋はとの数を増し, 間屋を中心とし た生産体制々確立をみた。

6. 問屋は(1)本問屋(2)問屋並(3)小增・新問屋(4)1795年に加わつた問屋という順序で成立 した。問屋並の立地は本問屋の空白地を満たす形で行われそが，新問屋の立地は前の 2 者の勢力賸に割込む結果となつた。 
7. 幕末の争乱と明治維新の政治・経済体制の変革の結果, 八溝山地内部の問屋は廃業 し，それ以後は山地と平地の接触地であり，交通上のすぐれた位置を占める烏山に問 屋が集中して立地する現象がみられた。

〔附記〕本稿を終るとあたり, 調査研究補助金を支給された財団法人製紙博物館長・成 田潔英氏, 終始御指導を願つた河野徳吉氏, 懇切な御助言をいただいた岩田博士はじめ 東京学芸大の諸先生，並びそ御協力いただいた方々と深謝意を表する。度招，至らな い点てついて諸賢の御教示を賜われげ幸甚の至りである。

\section{主要参考交献}

1. 竹内源助 (1793)：諸国紙日記（写本・製紙博物館藏）

2. 小室実（荻城県那珂郡檜沢村）所蔵(1795)：紙菼買掟問屋定法書上帳

3. 同 (1822)：株仲間飞関する文書

4. 関沢三郎（苂城県那珂郡御前山村）所蔵：雜事控，御用留などの古記録

5. 大森勝之介（苂城県那珂郡長含村）所藏：江戸問屋飞あてた書簡

6. 小野武雄編 (1941)：日本農民更料聚料・第 11 巻 P.500

7. 寿岳文章・静子(1943)：紙澽村旅日記 P.P.20-28

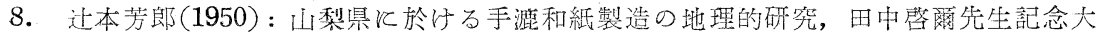
塚地理学会論交集 P.P.219-228

9. 河野德吉・海野福寿(1955)：江戸時代の地方紙問屋——常陸国那珂郡関沢家を中心 として——，紙及パルプ，6 巻 1 号 P.P.21-24

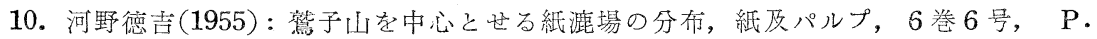
P. 14-20

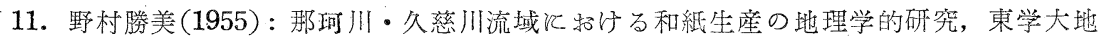
理学会誌 4 号 P.P.10-17 